symptomatic improvement. This trend probably reflects the spontaneous course of the disease, as medical treatment (diet, antacids, and anticholinergics) has had no convincing effect in controlled studies. ${ }^{5-7}$ The introduction of the $\mathrm{H}_{2}$-receptor antagonist cimetidine has greatly altered the prospects of medical treatment, as short-term treatment with this drug promotes ulcer healing and symptomatic remission, ${ }^{8}$ and the efficacy of long-term treatment is being investigated. Our results are important in this context as they suggest that most patients with duodenal ulcer will need only intermittent or continuous cimetidine treatment for a limited period.

The overall mortality of the patients in this study was not significantly higher than that of the general population, but this was because of the relatively small number of patients. The cohort studied was part of a larger sample of 1475 patients with duodenal ulcer forming the basis of an epidemiological study which showed a significant excess mortality during the first one or two years after diagnosis. The increased mortality in that study was confined to the cases diagnosed during an admission to hospital. ${ }^{9}$

Bleeding episodes had occurred equally often among patients who had a crater at the time of diagnosis and those who had only deformity of the duodenal cap. This observation suggests that deformity alone is a reliable sign of duodenal ulcer disease, and the higher incidence of surgical treatment among patients with a crater may simply imply that before the introduction of duodenoscopy surgeons were more reluctant to operate on patients whose ulcer had not been shown by barium-meal examination.

This study has wider implications, as the higher degree of accuracy of the mean predictions may suggest that the collective experience of the medical profession is reliable, though differences in the experience of individual doctors cause prognosis to be less precise. All clinical decision-making depends on predictions, which are often based on uncontrolled experience and not on results of clinical research, and it might prove valuable to study the precision and accuracy of doctors' prognostic estimates in other diseases.

\section{References}

${ }^{1}$ Fry, J, British Medical fournal, 1964, 2, 809.

2 Bonnevie, O, Scandinavian fournal of Gastroenterology, 1975, 10, 231.

${ }^{3}$ Bonnevie, O, Scandinavian fournal of Gastroenterology, 1975, 10, 385.

4 Wulff, H R, Rational Diagnosis and Treatment. Oxford, Blackwell, 1976.

5 Buchman, E, et al, Gastroenterology, 1969, 56, 1016

${ }^{6}$ Kaye, M E, et al, Gut, 1970, 11, 559.

' Sturdevant, R A L, et al, Gastroenterology, 1977, 72, 1.

${ }^{8}$ British Medical fournal, 1976, 2, 1975.

9 Bonnevie, O, Ugeskrift for Laeger, in press.

\title{
Decreased tuftsin concentrations in patients who have undergone splenectomy
}

\author{
ZVI SPIRER, VERA ZAKUTH, SAMUEL DIAMANT, W MONDORF, T STEFANESCU, \\ YITZHAK STABINSKY, MATI FRIDKIN
}

British Medical fournal, 1977, 2, 1574-1576

\begin{abstract}
Summary
Serum tuftsin concentrations were measured, using a radioimmunoassay developed in Israel, in normal subjects and in patients who had undergone splenectomy. Concentrations in those who had undergone traumatic and elective splenectomy were much lower. The tuftsin concentration in 38 patients with Hodgkin's disease who had undergone splenectomy during staging laparotomy was not significantly different from the mean concentration in other patients who had had elective splenectomy. In four patients who underwent splenectomy for non-malignant haematological disorders measurements
\end{abstract}

\footnotetext{
Paediatrics Department A, Municipal-Governmental Centre, Tel Aviv, Israel

ZVI SPIRER, MD, physician

VERA ZAKUTH, MSC, scientist

SAMUEL DIAMANT, MD, physician
Zentrum der Innern Medizin der Johann Wolfgang Goethe Univers- ität, Frankfurt am Main, West Germany
W MONDORF, MD, physician
T STEFANESCU, MD, physician

Department of Organic Chemistry, Weizmann Institute of Science, Rehovot, Israel

YITZHAK STABINSKY, MSC, scientist

MATI FRIDKIN, PHD, scientist
}

made before and after operation showed that tuftsin concentrations fell significantly in the days after operation.

The increased susceptibility to overwhelming infections of patients with Hodgkin's disease and others who have undergone splenectomy may be related to the low tuftsin concentrations. As pre-splenectomy tuftsin concentrations in patients with Hodgkin's disease were normal, the practice of performing staging laparotomy and splenectomy in patients with Hodgkin's disease should perhaps be reconsidered.

\section{Introduction}

Fulminant bacterial infections are now widely accepted to be a serious complication after splenectomy. ${ }^{1-6}$ But the incidence of sepsis in patients who have undergone elective splenectomy seems to differ from that in those who have had their spleens removed because of abdominal trauma with rupture of the spleen. ${ }^{5}$ Splenectomy has detrimental consequences because of the spleen's function in maintaining defence mechanisms against bacteria. The spleen plays a particularly important part in controlling the phagocytic capacity of polymorphonuclear leucocytes, and Najiar et al have found defective phagocytosis in the leucocytes of humans and animals who have undergone splenectomy. They attributed this defect to the absence of tuftsin, ${ }^{8}$ a basic tetrapeptide produced in the spleen that acts as a phagocytosis-stimulating agent of both polymorphonuclear leucocytes and macrophages. ${ }^{9}$

Tuftsin has recently been synthesised, ${ }^{1011}$ and the biological 
activity of the synthetic substance and its identity with the natural peptide have been shown in vitro by phagocytic assay ${ }^{9}$ and the quantitative nitroblue tetrazolium reduction test. ${ }^{12} \mathrm{We}$ have recently developed a radioimmunoassay for measuring serum tuftsin concentrations, ${ }^{13}$ and we report here the results of our evaluation of tuftsin concentrations in a large group of patients who had undergone splenectomy including some with Hodgkin's disease.

\section{Patients and methods}

We studied 35 healthy medical and nursing students $(21$ men and 14 women) aged $19-35$ years and 108 patients from the Municipal Governmental Medical Centre, Tel Aviv University, and the Zentrum der Inneren Medizine, Goethe Universität Klinikum, Frankfurt, who had undergone splenectomy one to 20 years earlier. The patients included 50 who had had traumatic splenectomy, 20 who had had elective splenectomy, and 38 with Hodgkin's disease who had had splenectomy during staging laparotomy (table I).

TABLE I-Clinical data on patients studied

\begin{tabular}{|c|c|c|c|c|}
\hline Group & $\begin{array}{c}\text { No of } \\
\text { patients }\end{array}$ & male female & $\begin{array}{c}\text { Age } \\
\text { (years) }\end{array}$ & $\begin{array}{c}\text { Time } \\
\text { elapsed } \\
\text { since } \\
\text { splenectomy } \\
\text { (years) }\end{array}$ \\
\hline $\begin{array}{l}\text { Normal subjects } \\
\text { Traumatic splenectomy } \\
\text { Elective splenectomy: } \\
\text { Spherocytosis } \\
\text { Idiopathic thrombo- } \\
\text { cytopenic purpura } \\
\text { Gaucher's disease } \\
\text { Splenic cyst } \\
\text { Hodgkin's disease after } \\
\text { splenectomy } \\
\text { Hodgkin's disease } \\
\text { before splenectomy } \\
\text { Miscellaneous }\end{array}$ & $\begin{array}{l}35 \\
50 \\
20 \\
8 \\
9 \\
2 \\
1 \\
38 \\
6 \\
4\end{array}$ & 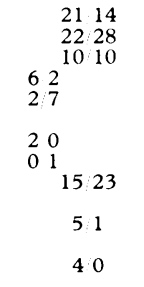 & $\begin{array}{c}20-60 \\
14-40 \\
7 \quad 12-28\end{array}$ & $\begin{array}{l}1-20 \\
1-12\end{array}$ \\
\hline
\end{tabular}

A further six patients with Hodgkin's disease were also studied before they underwent splenectomy, and four with miscellaneous conditions had their tuftsin concentrations measured before and after splenectomy.

A 5-ml sample of venous blood was obtained from each patient. The serum was separated, immediately frozen, and stored at $-18^{\circ} \mathrm{C}$ for up to 3 months.

Radioimmunoassay-The procedure has been described in detail elsewhere. ${ }^{13}$ Briefly, synthetic tuftsin was conjugated in bovine serum albumin, and this conjugate was used to immunise rabbits. The specific antibodies thus produced were subjected to radioimmunoassay. Analysis was performed on the water-soluble fraction left after short treatment of the serum sample with trypsin followed by ethanolic precipitation of the serum protein..$^{13}$

White blood counts and immunoglobulin determinations (by immunodiffusion) were performed on all the patients with Hodgkin's disease.

\section{Results}

The amounts of material immunochemically related to tuftsin found in the various sera are shown in table II. Statistical examination (Student's $t$ test) showed a significant difference $(P<0.001)$ between

TABLE II-Mean serum tuftsin concentrations (: $S E$ ), as determined by radioimmunoassay, in trypsinised serum of healthy subjects and patients who had undergone splenectomy

\begin{tabular}{c|c|c|c|c}
\hline Group: & $\begin{array}{c}\text { Normal } \\
\text { subjects }\end{array}$ & $\begin{array}{c}\text { Traumatic } \\
\text { splenectomy }\end{array}$ & $\begin{array}{c}\text { Elective } \\
\text { splenectomy }\end{array}$ & $\begin{array}{c}\text { Hodgkin's } \\
\text { disease after } \\
\text { splenectomy }\end{array}$ \\
\hline $\begin{array}{c}\text { Serum tuftsin } \\
(\mathrm{ng} / \mathrm{ml})\end{array}$ & $255 \cdot 71 \pm 10 \cdot 27$ & $234 \cdot 34 \pm 10 \cdot 22$ & $118 \cdot 00 \pm 7 \cdot 89$ & $126 \cdot 05 \pm 10 \cdot 27$ \\
\hline
\end{tabular}

concentrations in the normal subjects and those in the patients who had undergone splenectomy electively or because of Hodgkin's disease, whereas there was no significant difference in concentration between the normal subjects and those who had had a traumatic splenectomy. Similarly, patients who had had an elective splenectomy for Hodgkin's disease and those who had had one for other causes did not differ significantly in their tuftsin concentrations.

In the six patients who were studied immediately after Hodgkin's disease had been diagnosed and before splenectomy was performed the mean tuftsin concentration was $246 \cdot 22 \pm 8 \cdot 31 \mu \mathrm{g} / \mathrm{l}$ and thus not significantly different from normal.

There were no differences in tuftsin concentration between adults and children.

All four patients who were studied before and after splenectomy showed a considerable fall in tuftsin concentrations after the operation. Two patients with spherocytosis had initial concentrations of 261 and $235 \mathrm{~kg} / \mathrm{l}$, which fell to $112 \mathrm{\mu g} / 1$ and $87 \mu \mathrm{g} / \mathrm{l}$ respectively after splenectomy. A patient suffering from an epidermoid splenic cyst had a normal value of $252 \mu \mathrm{g} / \mathrm{l}$ before operation and a value of $45 \mu \mathrm{g} / \mathrm{l}$ two weeks after splenectomy. A 7-month-old infant in whom a spleen torsion was diagnosed had a tuftsin concentration of $98 \mathrm{ng} / \mathrm{ml}$ three days after the incident (and before splenectomy) but two weeks and two months after splenectomy showed values of $50 \mathrm{ng} / \mathrm{ml}$ and 40 $\mathrm{ng} / \mathrm{ml}$ respectively.

\section{Discussion}

Infections attributed to splenectomy are acute, fulminating, septicaemic diseases that often lead to death within hours of the first symptoms. Indeed, the risk of this type of infection is even higher after splenectomy performed because of an underlying disease. Nevertheless, serious, even fatal, infections occur in hyposplenic patients without predisposing disease. ${ }^{34}$ It is therefore difficult to determine whether the sensitivity of the patients is due to the splenectomy itself or to the reason for splenectomy. For example, there are conflicting data about the risk of infections in children with Hodgkin's disease who have undergone splenectomy. Although the available data come from retrospective studies, children with Hodgkin's disease who were treated before splenectomy became an accepted part of the management of this condition seem to have been less prone to infection than those treated more recently with laparotomy and splenectomy. ${ }^{14}$ In a recent study ${ }^{15} 20$ episodes of fulminant bacterial infections were reported in 18 out of 200 children who had undergone splenectomy for Hodgkin's disease. About half the infections were induced by Gram-positive bacteria with a predominance of pneumococci and streptococci. These types of infections are well known in patients who have undergone splenectomy for any reason. But the nature of the increased susceptibility to infections in patients who have had splenectomies has not been satisfactorily explained, as the role of the spleen in immunity is complex.

The spleen is an important source of opsonins and also serves as a site for the synthesis of specific antibodies and the regulation of both $\mathrm{T}$ and B lymphocytes. Studies have not, however, shown any serious permanent disturbance in these functions (except opsonisation $^{16}$ ), although defective phagocytosis due to tuftsin deficiency is well documented in patients who have undergone splenectomy. ${ }^{8}$

The relatively normal tuftsin concentrations found in our traumatic group may have been accounted for by Najiar's suggestion $^{9}$ that splenic tissue is implanted in the abdomen during the spleen rupture. The fact that tuftsin concentrations are lower and the risk of fulminant infection is higher after elective splenectomy than after traumatic splenectomy may suggest that tuftsin plays an important role in the defence against bacterial infection.

The serum tuftsin concentrations in our patients with Hodgkin's disease fell within the range of those of patients electively splenectomised for other diseases. Unfortunately, we did not have the opportunity to test more than six patients with Hodgkin's disease before splenectomy and thus we could not compare their tuftsin concentrations with those of the larger group of 
patients with Hodgkin's disease who had undergone splenectomy. Nevertheless, the normal pre-splenectomy concentrations are consistent with the fact that in Hodgkin's disease splenic function remains intact despite the attack on the reticuloendothelial system. ${ }^{17}$ Our results suggest that the practice of performing staging laparotomy and splenectomy in patients with Hodgkin's disease should be reconsidered. ${ }^{1 \times}$

Najiar et al determined the activity of tuftsin in serum by using the polymorphonuclear leucocyte-bacteria phagocytosis system, ${ }^{8}$ but this is an indirect qualitative assay requiring a large volume of blood and much time. Our radioimmunoassay can measure tuftsin qualitatively, only a little serum is needed, and the method is relatively simple. The assay is reproducible: results obtained from the same subjects on different days and different times of day showed a high degree of correlation $(\mathrm{r}=0.98)$.

It seems important that we should use our method to evaluate tuftsin concentrations in the familial tuftsin deficiency syndrome as well as in other hyposplenic states, such as congenital asplenia, ${ }^{19}$ coeliac disease, ${ }^{20}$ ulcerative colitis, ${ }^{21}$ splenic atrophy, ${ }^{19}$ splenic infarction, and premature birth. We are currently investigating a group of patients suffering from sickle-cell anaemia. ${ }^{22}$ The existence of a simple and reliable method for measuring tuftsin concentrations in human serum may perhaps be important in managing patients in hyposplenic states. The results may help to determine the necessity and optimum duration of prophylactic antibiotic treatment, and, as recently suggested, ${ }^{23}$ it may be worth while to consider the use of tuftsin as a drug.

\section{References}

1 Eraklis, A J, et al, New England fournal of Medicine, 2967, 276, 1225.

2 Smith, C H, et al, fournal of Diseases of Childhood, 1956, 92, 507.

${ }^{3}$ Bulfanz, J R, et al, Fournal of Pediatrics, 1976, 88, 458.

- Grinblat, J, and Gilboa, Y, American fournal of Medical Sciences, 1975, 270, 523.

5 Lancet, 1967, 1, 1167.

${ }^{6}$ Walter, W, British fournal of Surgery, 1976, 63, 36.

7 Constantopoulos, A, Najiar, V A, and Wish, J B, American fournal of Diseases of Children, 1973, 125, 663.

${ }^{8}$ Najjar, V A, and Nishioka, K, Nature, 1970, 228, 672.

${ }^{9}$ Najiar, V A, and Constantopoulos, A, Fournal of Reticuloendothelial Society, 1972, 12, 197.

${ }^{10}$ Nishioke, K A, et al, Biochemical and Biophysical Research Communications, $1972,47,172$.

${ }^{11}$ Fridkin, M, et al, Biochemica Biophysica Acta, 1977, 496, 203.

12 Spirer, Z, et al, fournal of Clinical Investigation, 1975, 55, 198

${ }^{13}$ Spirer, Z, et al, European fournal of Immunology, 1977, 7, 69.

${ }^{14}$ Donaldson, S S, et al, New England fournal of Medicine, 1972, 287, 69.

${ }^{15}$ Chilcote, R R, Baehner, R L, and Hammond, D, New England fournal of Medicine, 1977, 295, 798.

${ }_{16}$ Andersen, V, Cohn, J, and Sorensen, S F, Acta Pediatrica Scandinavica, $1976,65,409$.

17 Sheagran, J N, Block, J B, and Wolff, S M, Fournal of Clinical Investigation, 1967, 46, 855.

${ }^{18}$ British National Lymphoma Investigation, Clinical Radiology, 1975, 26, 151.

19 Waldman, J D, et al, fournal of Pediatrics, 1977, 90, 555.

${ }^{20}$ Wardrop, C A J, et al, Lancet, 1965, 2, 4.

${ }^{21}$ Ryan, F P, et al, Lancet, 1974, 2, 318.

22 Pearson, H A, Spencer, R P, and Cornelius, E A, New England fournal of Medicine, 1969, 281, 923.

${ }^{23}$ Mikulski, S M, et al, New England fournal of Medicine, 1977, 296, 454.

(Accepted 14 October 1977)

\title{
Comparison of metformin and chlorpropamide in non-obese, maturity-onset diabetics uncontrolled by diet
}

\author{
B F CLARKE, I W CAMPBELL
}

British Medical fournal, 1977, 2, 1576-1578

\section{Summary}

The clinical effectiveness of metformin was compared with that of chlorpropamide in closely similar groups of 216 non-obese patients recently diagnosed as cases of maturity-onset diabetes that could not be controlled by diet. The incidences of primary and secondary drug failures in each group and the numbers of patients satisfactorily maintained on each of the hypoglycaemic agents throughout the first year proved remarkably similar. In 61 of the successfully treated patients who were studied by crossover to the other drug and observed for a further year the mean blood glucose concentrations at the end of the year were roughly comparable, but the mean weight response was a small loss of $1.5 \pm 3.8 \mathrm{~kg}$ with metformin but a gain of $4.6 \pm 3.9 \mathrm{~kg}$ with chlorpropamide.

Thus for non-obese, maturity-onset diabetics whose disease cannot be controlled by diet and who require oral treatment sulphonylureas and biguanides are equally effective, the choice depending on whether the patient is underweight and the severity of symptoms.

\footnotetext{
Diabetic and Dietetic Department, Royal Infirmary, Edinburgh EH3 9YW

B F CLARKE, FRCP, consultant physician and senior lecturer

I W CAMPBELL, MRCP, senior registrar
}

\begin{abstract}
Introduction
Since sulphonylureas became available before biguanides and have fewer side effects they have tended to become the treatment of choice in maturity-onset diabetes that cannot be controlled by diet. Few controlled studies have therefore been carried out to compare the clinical effectiveness of sulphonylureas and biguanides, particularly metformin, in this condition. The present study was designed specifically to compare the clinical responses to metformin and chlorpropamide in non-obese, maturity-onset diabetics uncontrolled by diet.
\end{abstract}

\section{Patients and methods}

Patients considered for inclusion in the study were aged 40-79 years and had been diagnosed as diabetic less than three months previously. None was ketotic or obese (body weights below $109 \%$ (below $100 \%$ in most cases) of standard weight), and none had already received an oral hypoglycaemic agent or insulin. Patients regarded as diet failures included: (a) true diet failures-namely, patients who despite adherence to diet for at least four weeks had a two-hour postprandial blood glucose concentration exceeding $14.0 \mathrm{mmol} / \mathrm{l}$ $(252 \mathrm{mg} / 100 \mathrm{ml})$, often with persisting symptoms and very little weight gain; and $(b)$ predicted diet failures-namely, patients for whom a trial on diet alone was not believed to be justified because of severe thirst and polyuria, loss of weight, and initial blood glucose concentrations exceeding $14.0 \mathrm{mmol} / \mathrm{l}$, and often much higher. Patients known to have severe disease such as congestive cardiac failure or neoplasia were excluded from the study, as were patients who had been receiving diabetogenic drugs.

Two hundred and nineteen patients ( 86 men and 133 women) 